\title{
On the relationship between reflective teaching and
} teachers' burnout

\author{
Javadi, Farzaneh $\bowtie$ \\ Allameh Tabatabaei University, Iran (Javadi.farzaneh@gmail.com) \\ Khatib, Mohammad \\ Allameh Tabatabaei University, Iran (mkhatib27@yahoo.com)
}

Received: 8 November 2013

Available Online: 6 February 2014
Revised: 20 December 2013 DOI: $10.5861 /$ ijrsl1.2014.614

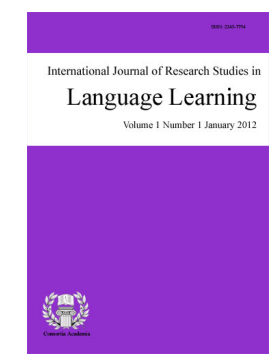

ISSN: $2243-7754$ Online ISSN: 2243-7762

OPEN ACCESS

Accepted: 5 February 2014

\section{Abstract}

Few studies with a focus on teachers and their characteristics have attempted to shed light on the effects teachers' dissatisfaction and demotivation can have on their professional development (Ozer \& Beycioglu, 2010; Zamani Rad, 2010). Surprisingly, no studies have addressed the relationship between their feelings of dissatisfaction and burnout with reflective teaching. As many as 170 Iranian EFL teachers in different private language teaching institutes participated in the study. Data were collected using Maslach Burnout Inventory (Maslach, Jackson, \& Leiter, 1996) and reflective teaching measurement scale (Behzadpoure, 2007). Correlation analysis indicated that teachers' reflection was significantly and inversely related to their feeling of burnout $(\mathrm{r}=-80, p<0.05)$. The Step-Wise Multiple Regression also showed that the components of burnout i.e. emotional exhaustion, depersonalization, and reduced personal accomplishment can considerably predict teachers' reflection. The findings offer some implications for in-service and pre-service teacher preparation programs.

Keywords: reflective teaching; burnout; emotional exhaustion; depersonalization; reduced personal accomplishment 


\section{On the relationship between reflective teaching and teachers' burnout}

\section{Introduction}

In an era in which changes are so rapid, education has become increasingly important for the success of all societies. In this regard, teachers should raise their levels of achievement in educational system in order to meet the high standards of teaching. To this end, the need for teacher education has been a frequent subject-matter in the area of language teaching in recent years and has been given a special focus. Flexibility of teaching is so great that different factors can greatly influence it, and impose various roles on teachers, which is the reason for the existence of miscellaneous approaches to teaching.

During the second half of the twentieth century, a shift took place in learning and teaching perspectives, specifically in the area of language teaching and learning. A cognitivist and constructivist view was replaced with the previous behaviorist and positivistic one, which was later followed by the appearance of a sociocultural perspective in the 1990s.

\subsection{Reflective Teaching}

Dewey (1933) believed, "teachers are not just passive curriculum implementers, but they can also play an active role in curriculum design and educational reform" (p. 49). He also indicated that teaching should be a practice including a process of hypothesizing, investigation, reasoning, testing and evaluation, leading to modification and if necessary further investigation and this practice of teaching is what he considers as "reflective teaching".

Reflective teaching is an approach to teaching which requires "paying critical attention to the practical values and theories which inform everyday actions, by examining practice reflectively and reflexively" (Bolton, 2010 , p. 22). In other words it means a process of self-observation and self-evaluation of teachers during their teaching experience. Dewey (1933) noted that reflection is a purposeful attempt to ponder on teaching and educational experiences, leading to further student and teacher growth and learning. Moreover, Richards (1990) sees reflection as a key component of teacher development, too. According to Farrell (2004) there are three major types, or moments, of reflective practice that are concerned with teacher reflection.

Reflection-in-action - This type of reflection guides teachers' in-the-moment of decision-making, and depends on their interactions with learners and happens when teachers take for granted their knowledge of teaching as many of their actions have become routine while teaching (Farrell, 2004).

Reflection-on-action - It's a kind of reflection that includes planning and looking back on one's practice. Contemplation on what was done to find out how knowing at the time of teaching may have contributed to an unexpected action, thus it's a metacognitive process that includes deliberate thinking (Farrell, 2004)

Reflection-for-action - This type of reflection is proactive in nature. Reflection-for-action is the desired outcome of previous types of reflection, since all the awareness achieved through other types of reflection is not fruitful unless they are used as guidance for the future action (Farrell, 2004).

Reflective practice was identified by Farrell (1999), as a practice which can instruct teachers to negotiate on the ground rules to make their teaching practice more effective. Reflective practice can offer teachers opportunity to explore attitudes, develop management skills, and reflect on the ethical implications of practice in classrooms and thereby encourages teachers to step back and critically reflect not only on how they teach, but also on why they teach in a particular way. In short, it helps in the evolution of good teaching practices.

The concept of reflective practice also arose out of the need to counteract burnout in the teaching profession, 
Burn out practitioners find teaching repetitive and routine (Munby \& Russell, 1990). They also indicated that if teachers become inattentive to ponder and adjust the categories of their knowing-in-action, they may suffer from boredom and in extreme cases from burnout. Thus, this experience which may have debilitative effects in teachers' professional development, calls special attention to be given to psychological problems teachers may face during their professional life.

\subsection{Burnout}

According to Maslach et al. (2001), professional stress can have deep psychological, cognitive, emotional, behavioral, and somatic; effects such as exacerbated fatigue, and lack of activity. People whose profession calls for a stressful condition come across great problems both psychologically and physically. Initially coined by Freudenberger in 1974, the term "burnout" is defined by Maslach (1993) as "a psychological syndrome of emotional exhaustion, depersonalization, and reduced personal accomplishment that can occur among individuals who work with other people in some capacity." Burnout has been identified as an affective chronic reaction due to prolonged exposure to work stress (Maslach, Schaufeli, \& Leiter, 2001; Capel, 1987). Maslach et al. (2001) argued that as a syndrome, burnout is "an emotional state which generates the loss of positive, optimistic beliefs and feelings, sympathy (compassion), and respect for others. This fatigue is often accompanied by physical fatigue, illnesses and disorders which develop towards a psychosomatic syndrome.”

According to Maslach et al. (2001), burnout consists of three dimensions: (a) emotional fatigue or exhaustion, involve feelings of being depleted of one's emotional and physical resources, as a consequence of intense physical, affective and cognitive strain, i.e. as a long-term consequence of prolonged exposure to certain job demands. (b) depersonalization, originally refers to distancing oneself emotionally from service recipients, it is a state of detachment from students, parents, and other teachers that disturbs a teacher's personal and professional life, and (c) a reduced sense of personal accomplishment which is described as a person's negative self-evaluation regarding his or her job performance.

In order to come up with a clear picture of the burnout process, an extensive number of investigations have been carried out. According to studies in the literature, teacher burnout can be triggered by organizational characteristics such as number of students, professional recognition or prestige expenditure, working conditions, poverty enrollment, level of specialization, student demographics which can include student disruptive behavior, lack of resources, relationship with colleagues, and social support (Abel \&Sewell, 1999; Borg et al., 1991; Dick \& Wagner, 2001).

The recent changes which can be evidenced in the language teaching perspectives highlight the great role teachers play on the learners' success and require teachers to get aware of the importance of their attitudes, beliefs and their being critical of their teaching experiences. This is regarded as reflective teaching through which teachers can develop changes in attitude and awareness. This reflectivity can benefit not only their professional growth as teachers but also the by-product of their teaching regarding their students. Moreover, emotions and feelings can have a paramount effect on teachers' professional life. Teachers being highly emotional can bring enormous breakthroughs in their profession. Therefore, the best should be done to carry out studies which aim at improving this facet and recognizing the effects of elements which can result in decreasing this emotionality; and burnout is one of such elements.

\subsection{Research Questions}

Various studies investigated burnout considering it in various EFL contexts; however no study addressed the potential effect the feeling of burnout may have on successful teaching approaches such as reflective teaching. Accordingly, to bridge this gap, this study aims to find the answer of the following questions: 
Javadi, F. \& Khatib, M.

1. Is there any significant relationship between reflective teaching and teachers' feeling of burnout?

2. Can the components of burnout significantly predict teachers' reflection?

\section{Methodology}

\subsection{Participants}

170 EFL teachers from different Language institutes in Tehran participated in this research. Via a convenience sampling data collected from both male and female teachers teaching English as a foreign Language in Language institutes. Except for a small number, all of them had a degree in English (BA, MA).They were teaching different levels of English (elementary, intermediate, and advanced). Out of 200 questionnaires distributed among participants, only170 questionnaires were suitable for the purpose of the study

\subsection{Instrumentation}

Reflective Teaching Questionnaire: The instrument which was used for measuring reflective teaching in this study was the one devised by Behzadpour (2007) that included 42 items in a multiple-choice test format. It is a five-point likert scale, consisting of five options of never, rarely, sometimes, often, and always, which has been devised based on six factors; Cognitive, Metacognitive, Affective, Practical, Critical, and Moral. Behzadpour's questionnaire was chosen for the purpose of this study because it was devised for measuring teachers' reflection in the context of Iran and it enjoys a high reliability of .90 as a measuring instrument for teacher reflectivity (Behzadpoure, 2007).

Maslach Burnout Inventory (MBI; Maslach \& Jackson, 1986); Maslach inventory, a questionnaire developed by Maslach and Jackson and was used to measure teachers' perceived amount of burnout because to the researchers' best knowledge it is the most well-known and reliable scale in this area. The inventory includes 22 questions with a 6-point Likert scale consisting of three sub-dimensions; emotional exhaustion sub-dimension (EE), depersonalization sub-dimension (D), and personal accomplishment sub dimension (PA). Higher emotional exhaustion and depersonalization and lower personal accomplishment cause high burnout status. The Cronbach Alpha values of dimensions: emotional exhaustion .90; depersonalization .79; personal accomplishment .71 (Maslach, 1993).

\subsection{Interview}

In order to delve more deeply into the factors contributing to teacher demotivation, burnout and reflection from the participant teachers' perspective and to ascertain the reliability and accuracy of their responses to the questionnaire items, Qualitative analysis was run. Only eighteen subjects were willing to cooperate in the interview as the representative sample of the study. As long as it was possible, it was attempted to select the interviewees from different institutes in order to have a sample representative of all participants and avoid any bias. It was attempted to include teachers form both genders in all experience and age groups previously defined in the study.

\subsection{Data analysis}

Quantitative analysis was carried out to find the answer of the questions. Pearson-Product Moment correlation was run so as to explore if teachers' reflection has any statistically significant relationship with their burnout. The data based on the participants' responses to both questionnaires we reanalyzed with the help of SPSS (version 16) program. Then multiple regressions were carried out to find out whether the components of burnout could predict any degree of teachers 'reflection. 


\section{Results}

\subsection{Teachers' reflection and burnout}

The relationship between teachers' reflection and their sense of burnout was investigated using Pearson product-moment correlation coefficient. Preliminary analyses were performed to ensure no violation of the assumptions of normality, linearity and homoscedasticity. The results revealed a strong, negative correlation between the two variables $r=-.80, n=170, p<.0005$, high levels of teachers' reflection associated with lower levels of burnout. This means the higher the teachers' reflection is, the lower the amount of the amount of burnout they feel. (Table 1)

\section{Table 1}

Pearson Correlation for Reflective Teaching and Burnout

\begin{tabular}{ccc}
\hline$r$ & $\mathrm{~N}$ & $p$ \\
\hline-.80 & 170 & .000 \\
\hline
\end{tabular}

\subsection{Predictive power of components of burnout}

A standard regression analysis was run to predict teachers' degree of reflection through components of burnout and the 3 components were entered as independent variables. As displayed in Table 2, components of burnout; emotional exhaustion (E.E), depersonalization (DEP), and personal accomplishment (P.A) are the predictors entered into the regression model.

\section{Table 2}

Regression model summary of reflection and components of burnout

\begin{tabular}{|c|c|c|c|c|c|}
\hline Model & df & $F$ & $\mathrm{R}^{2}$ & Adjusted $\mathrm{R}^{2}$ & $P$ \\
\hline $\begin{array}{l}\text { 1. Regression } \\
\text { Residual } \\
\text { Total }\end{array}$ & $\begin{array}{c}1 \\
168 \\
169\end{array}$ & 133.04 & .442 & .439 & $.000^{\mathrm{a}}$ \\
\hline $\begin{array}{l}\text { 2. Regression } \\
\text { Residual } \\
\text { Total }\end{array}$ & $\begin{array}{c}2 \\
167 \\
169 \\
\end{array}$ & 81.031 & .492 & .486 & $.000^{\mathrm{b}}$ \\
\hline $\begin{array}{l}\text { 3. Regression } \\
\text { Residual } \\
\text { Total }\end{array}$ & $\begin{array}{c}3 \\
166 \\
169 \\
\end{array}$ & 61.444 & .526 & .518 & $.000^{\mathrm{c}}$ \\
\hline
\end{tabular}

The R- square for emotional exhaustion is.44, i.e. emotional exhaustion can predict 44 percent of the teachers' reflection. As the statistics show, Emotional Exhaustion $(\beta=-.66, p \leq 0.05)$, Depersonalization $(\beta=$ $-.30, p \leq .05)$, and personal Accomplishment $(\beta=-.23, p \leq .05)$ were found to make significant contributions to the teachers' reflection.

Table 3

Multiple Regressions on the Dependent Variable

\begin{tabular}{lcccc}
\hline Variables & $\mathrm{B}$ & $\beta$ & $t$ & $P$ \\
\hline Emotional Exhaustion & -2.471 & -.665 & -11.53 & .000 \\
Depression & -1.881 & -.303 & -4.62 & .000 \\
Personal Accomplishment & -1.098 & -.235 & -3.43 & .000 \\
\hline
\end{tabular}

These results indicate that all three components of burnout correlate negatively with reflective teaching and 
Javadi, F. \& Khatib, M.

can predict it significantly.

\subsection{Qualitative Analysis: Semi-Structured Interview}

Semi-structured interviews consisting of five questions based on the research questionnaires were carried out to investigate participants' perceptions of the concepts thoroughly. Fourteen of the interview participants took part in face-to-face interviews, but four of the interviews were conducted by telephone due to geographic distance. Each interview was administered individually and was audio-taped. To analyze the qualitative data, audio-recordings of the interviews were transcribed and the answers were classified regarding the content and theme of their interview. The themes for each concept were selected based on the recurring of the ideas in interviewee participants' answers. Then the commonalities and differences in the themes identified and probed to come up with teachers' beliefs and practices regarding reflection and feeling of burnout.

Two of the interview questions were about burnout including "What do you think are the disadvantages and shortcomings of being a teacher?", "Can you briefly name the factors that demotivate you or make you dissatisfied with your job at times?" The transcriptions were analyzed and three main factors came out to be the main reasons of teachers' demotivation and lack of interest in their jobs, as reasons or beliefs on burnout were found to be similar in nature. A large sum of obtained data emphasized the vital importance of extrinsic motives such as contextual, financial, and students' factors.

From the teacher participants' perspective, the contextual and financial factors included institution restrictions and high expectations, long hours of work, the routine nature of teaching as a job, being exploited, low payment, and no prospects of promotion and progress. What follows is how some teachers elaborated on these factors in their own words:

"Most of the teachers including English teachers are usually overworked and underpaid. They have to put in a lot of effort especially for basic levels and not get much in return."

"In my experience, teaching basically has to teach the same things over and over again to mainly uninterested students. Despite all the efforts that a teacher makes, there are no considerable improvements or promotions waiting for her. This is really annoying."

Student Factors - Such factors greatly addressed those issues related to the learners' actions and attitudes such as lack of respect and appreciation toward their teachers, lack of interest and motivation to take classes seriously, and being held responsible by students and parents for the things that go wrong in the students' learning process. Here are two examples from the interview transcripts:

\footnotetext{
"Teaching entails so much effort and sacrifice. A teacher has to try hard to get her students involved, but when you don't see that motivation and interest on the learners' side, you too become less motivated."

"No matter how hard I try to enhance their learning ability and skill, always there are some parents to blame me for their children's failure."
}

To focus on the 3 interview questions related to reflective teaching, consisting of "Do you often think about the quality of your lesson before and after your class?", "Do you ever think about having full control over the content, objectives and teaching procedures and approaches that you use in your class?", "What measures do you usually take to improve the quality of your teaching?", the majority of the participants appeared to have an average amount of reflection.

Lesson Planning - Probing the responses to the first question, more than half of the participants claimed thinking about their lesson plans before and after their class, and as it is exemplified below, some even indicated writing them down; 
"I always write my lesson plan the night before my class because without lesson plan I may lose the track of time and get behind the schedule I have to finish till the end of the semester"

"Thanks God writing the lesson plan is not necessary in the institutes I'm teaching, but I always have a lesson plan in my mind. Even I think about what I'm going to ask"

Having Control over Content - The clear cut answers of the most responses was yes to the second question on the concept of reflection. Participants questioned obligatory lesson plans, methods, and strategies they had to follow. They said in order to be fruitful, methods, techniques, and lesson plans should be chosen and adjusted regarding the context of use. Even some mentioned the importance of teachers' creativity and freedom by stating;

"I always think about selecting materials, lesson plans, and strategies according the context of my class. I believe teachers should be free to use their creativity to make the best decisions about their leaner."

"I guess, this is kind of every teacher's dream. Teachers don't usually get much say in what to do in their own classes or what teaching procedures to follow and this, I think, really limits and weakens their true potential."

Techniques for Improving Reflection - To respond to the third question, a large number of them only mentioned the most common techniques in developing their reflection; such as establishing a clear set of class rules and behaviors, talking with colleagues about class issues and experiences and asking for advice, asking learners about their likes/dislikes in class, talking about strategies, backgrounds, and hobbies than writing a dairy or article about their teaching practice. Some of the responses for question three go as;

"I try to be prepared for my classes most of the time and learn from the things that go wrong in my classes. I also try to learn from my colleagues and what they have to offer. I like reading some practical teaching books sometime."

"I always think I'm responsible for my students' progress, I try my best, think about my weaknesses, and ask students whether they like my class, method. I ask about their interest and background to use them in my teaching, I check internet even I read articles to update my knowledge of teaching and use new strategies and technics."

\section{Discussion and conclusion}

\subsection{Teachers' Reflection, Burnout, and its Components}

A significant negative relationship found out between teachers' reflection and their feeling of burnout. The higher the degree of teachers' reflection, the less the degree of burnout teachers feel. In other words, the more the teachers have reflection and concern for developing their teaching skills, the less they have feelings of helplessness, disillusion, and emotional exhaustion.

Moreover, the results of regression analysis revealed that all the components were good predictors of teachers' reflection as they could predict 52 percent of reflection, with a 44 percent prediction rate; emotional exhaustion was the best predictor of teachers' reflection (See table 2). The positive effects of teachers' reflection and rumination over their classroom and teaching practice have been the subject of a large number of empirical studies. Research studies (Akbari, 2007; Davis, 2003; Farrell, 2007; Ross, 1990) draw extensively on the idea of improving the quality of language learning by motivating and informing teachers of the prosperous effects of their deliberation and reflection. They also agree that critical analysis of both practical and ethical dimensions of teachers' practice should be encouraged. The obtained results of this study again evidenced the findings of 
previous research studies in highlighting the fact that teachers' reflection not only fosters the quality and value of teachers' practice (Bolton, 2010), but also precludes emotional problems like burnout, they may encounter throughout their teaching span (Chan, 2007).

\subsection{Burnout and Reflection from Teachers Perspective}

All responses relevant to the phenomenon of interest from the interviews were noted. Surprisingly, despite the high degree of reflection evinced from the participants' responses in the questionnaires, during the interview except for few cases, extreme or high degrees of reflection were not detected. This may have happened due to the participants' lack of awareness of the concept of reflection or their attempt to sound more idealistic in their practice.

One of the factors that evidently played a key role in participants' teaching life is motivation. As a dynamic process, motivation can influence "working atmosphere, communication, productivity, cohesion, emotional state, cooperation, the process and control of self-fulfillment, and many others" (Forrando et al., 1996). Many of the participants declared to have no motivation for improving their teaching ability or even for updating their teaching knowledge. They said their efforts brought about no appreciation on the side of the officials, managers, and even students. For being reflective, teachers should examine their beliefs and values before, while, and after their teaching experience and feel responsible about what they are doing or how they are behaving in their classroom. Dewy (1916, p. 57) believes that "subconsciously or consciously, teachers may wish to promote a particular image of themselves".

\subsection{Burnout and Personal/Contextual Factors}

Considering the participants' responses, once again, the key role of contextual factors in the process of burnout was emphasized and introduced as the main detriment of burnout (Maslach et al., 2001). Also this is in line with studies on burnout which have found it to be highly affected by contextual factors such as physical workplace environment, number of students, and working conditions (Borg et al., 1991; Hakanen et al., 2006). Thus, in order to have a clearer picture of the burnout phenomenon in our institutes, the role of both personal and contextual factors should be considered. Although previous research in the literature has found negative correlations between teachers' perceived self-efficacy and their burnout levels (Dick \& Wagner, 2001; Chan 2007; Skaalvik \& Skaalvik, 2010), it seems that no matter how efficient teachers might believe themselves to be, the contextual factors that they have to deal with have stronger effects on their feelings of burnout.

There are various internal and external factors that can influence teachers' beliefs, attitudes, and classroom practice. Burnout is one of these factors that can negatively affect language teachers practice. Extrinsic factors including economic motives, no prospects of promotion and improvement, and student factors such as their lack of interest and motivation were found to be the main causes of burnout feelings from the teachers' point of view. This study has implications for our ELT officials to appreciate the important role of English teachers and their endless efforts in this field and also emphasizes the serious problems that English teachers face which need to be solved in order to have successful and emotionally healthy English teachers, and consequently successful and motivated English learners. Positive use of reflective teaching principles as a pedagogical tool can help teachers to improve their practice and be more efficacious in their classroom. Teachers should give more attention to what happens in their classroom before, after, and even at the moment of teaching. Their considerations, interpretations, deliberations and thoughts about their teaching experience can affect and improve their practice greatly and pave the way for learner's developments.

The findings of this study can be fruitful for teacher educators, institute managers, and government officials to raise language teachers' awareness of the dire importance of reflecting on their teaching experiences in order to understand the phenomenon of language teaching and learning from a deeper perspective and, in turn, come to a better understanding of the emotions they experience throughout their teaching career and provide them with 
On the relationship between reflective teaching and teachers' burnout

practical techniques for coping with any emotional problems they might happen to encounter.

\section{Reference}

Abel, M. H., \& Sewell, J. (1999). Stress and burnout in rural and urban secondary school teachers. The Journal of Educational Research, 92(5), 287-293. http://dx.doi.org/10.1080/00220679909597608

Akbari, R. (2007). Reflections on reflective teaching: A critical appraisal of reflective practices in L2 teacher education. System, 35, 192- 207. http://dx.doi.org/10.1016/j.system.2006.12.008

Babaei, M. (2009). An investigation of the relationship between reflective teaching and teachers' self-efficacy beliefs. Unpublished masteral thesis, Allameh Tabatabaei University, Tehran, Iran.

Behzadpour, F. (2007). Developing a measuring instrument for reflective teaching. Unpublished masteral thesis, Tarbiat Modares University, Tehran, Iran.

Bolton, G. (2010). Reflective practice, writing and professional development ( $3^{\text {rd }}$ ed.). California: SAGE publications.

Borg, M. G., Riding, R. J., \& Falzon, J. M. (1991). Stress in teaching: A study of occupational stress and its determinants, job satisfaction and career commitment among primary school teachers. Educational Psychology: An International Journal of Experimental Educational Psychology, 11, 59-75.

Capel, S. A. (1987). The incidence of and influences on stress and burnout in secondary school teachers. British Journal of Educational Psychology, 57, 279-288. http://dx.doi.org/10.1111/j.2044-8279.1987.tb00857.x

Chan, D. W. (2007). Emotional intelligence and components of burnout among Chinese secondary school teachers in Hong Kong. Teaching and Teacher Education, 22, 1042-1054. http://dx.doi.org/10.1016/j.tate.2006.04.005

Cohen, J. (1988). Statistical power analysis for the behavioral sciences. Hillsdale, NJ: Erlbaum.

Davis, E. A. (2003). Prompting middle school science students for productive reflection: Generic and directed prompts. The Journal of the Learning Sciences, 12(1), 91-142. http://dx.doi.org/10.1207/S15327809JLS1201_4

Dewey, J. (1901). Psychology and social practice. Chicago: The University of Chicago Press.

Dewey, J. (1916). Democracy and education: An introduction to the philosophy of education. New York: Macmillan.

Dewey, J. (1933). How we think: A restatement of the relation of reflective thinking to the educative process. New York D.C: Heath and company.

Dick, V. R., \& Wagner, U. (2001). Stress and strain in teaching: A structural equation approach. British Journal of Educational Psychology, 71, 243-259. http://dx.doi.org/10.1348/000709901158505

Farrell, T. (1999). Reflective practice in an EFL teacher development group. System, 27, 157-172. http://dx.doi.org/10.1016/S0346-251X(99)00014-7

Farrell, T. (2007). Reflective language teaching: From research to practice. New York: Continuum.

Farrell, T. (2001).Tailoring reflection to individual needs: A TESOL case study. Journal of Education for Teaching, 27(1), 23-38. http://dx.doi.org/10.1080/02607470120042528

Farrell, T. (2004). Reflective practice in action: 80 reflection breaks for busy teachers. Thousand Oaks, California: Corwin Press, Sage Publication Company.

Fernando, J., \& Perez, J. (1996). A measure of "burnout" in teachers: Catalan adaptation of the Maslach Burnout Inventory. Revista de Psiquiatria de la Facultad de Medicina de Barcelona, 23, 11-18.

Freudenberger, H. J. (1974). Staff burnout. Journal of Social Issues, 16, 159-165. http://dx.doi.org/10.1111/j.1540-4560.1974.tb00706.x

Freudenberger, H. J. (1975). The staff burnout syndrome in alternative institutions. Psychotherapy Theory Research and Practice, 12, 72-83. http://dx.doi.org/10.1037/h0086411

Hakanen, J. J., Bakker, A. B., \& Schaufeli, W. B. (2006). Burnout and work engagement among teachers. Journal of School Psychology, 43, 495-513. http://dx.doi.org/10.1016/j.jsp.2005.11.001

Maslach, C. (1976). Burned-out. Human Behavior, 9(5), 16-22.

Maslach, C. (1993). Burnout: A multidimensional perspective. In W. B. Schaufeli, C. Maslach, \& T. Marek, 
Professional burnout: Recent developments in theory and research (pp. 19-32). Taylor and Francis: Washington, DC.

Maslach, C., \& Jackson, S. E. (1981).The measurement of experienced burnout. Journal of Occupational Behavior, 2, 99-113. http://dx.doi.org/10.1002/job.4030020205

Maslach, C., \& Jackson, S. E. (1986). Maslach burnout inventory. Palo Alto, CA: Consulting Psychologist Press.

Maslach, C., Jackson, S., \& Leiter, M. (1996). Maslach Burnout Inventory Manual. (3 ${ }^{\text {rd }}$ ed.). Palo Alto, CA: CPP, Inc.

Maslach, C., Schaufeli, W. B., \& Leiter, M. P. (2001). Job burnout. Annual Review of Psychology, 52, $397-422$. http://dx.doi.org/10.1146/annurev.psych.52.1.397

Momenian, M. (2009). Investigating the relationship between emotional intelligence and burnout on teachers. Unpublished masteral thesis, Tarbiat Modares University, Tehran, Iran.

Munby, H., \& Russell, T. (1990). Metaphor in the study of teachers' professional knowledge. Theory into Practice, 29(2), 116-121. http://dx.doi.org/10.1080/00405849009543441

Özer, N. \& Beycioglu, K., (2010). The relationship between teacher professional development and burnout. Procedia Social and Behavioral Sciences, 2, 4928-4932. http://dx.doi.org/10.1016/j.sbspro.2010.03.797

Pallant, J. (1961). SPSS Survival Manual: a step by step guide to data analysis using SPSS. Sydney: Bookhouse.

Richards, J. C. (1990). Beyond training: approaches to teacher education in language teaching. Language Teacher, 14(2), 3-8.

Richards, J. C. (1998). Beyond training. New York: Cambridge University Press.

Richards, J. C. \& Farrell, T. (2005). Professional development for language teachers. New York: Cambridge University Press. http://dx.doi.org/10.1017/CBO9780511667237

Richards, J. C., \& Nunan, D. (1995). Second language teacher education. Cambridge: Cambridge University Press.

Richard, J. C., \& Schmidt, R. (2002). Language dictionary of language teaching and applied linguistic. London: Pearson Education.

Ross, D. (1990). Programmatic structures for the preparation of reflective teachers. In R. Clift, W. R. Houston, \& M. Pugach (Eds.), Encouraging reflective practice in education. New York: Teachers College Press.

Skaalvik, E. M., \& Skaalvik, S. (2010). Teacher self-efficacy and teacher burnout: a study of relations. Teaching and Teacher Education, 26, 1059-1069. http://dx.doi.org/10.1016/j.tate.2009.11.001

Vygotsky, L. S. (1978). Mind in society: The development of higher psychological processes. Cambridge, MA: Harvard University Press.

Zamani Rad, A., \& Rohani, N. (2010). Burnout and career self-concept among teachers in Mashhad, Iran. Procedia Social and Behavioral Sciences, 7, 464-469. http://dx.doi.org/10.1016/j.sbspro.2010.10.063

Zeichner, K., \& Liston, D. (1996). Reflective teaching: An Introduction. Mahwah, NJ: Lawrence Erlbaum. 


\section{Appendix}

Gender: $\quad$ Female $\bigcirc \quad$ Male $\bigcirc \quad$ Teaching Experience (years): age:

Degree: No Degree $\bigcirc \quad$ BA in English $\bigcirc \quad$ MA in English $\bigcirc \quad$ PhD in English

Degree in Other Fields of Study (please specify):

Please check the box that best expresses your current teaching situation.

Thank you very much for your time and cooperation.

\begin{tabular}{|c|c|c|c|c|c|c|}
\hline No & Items & $\begin{array}{l}\bar{D} \\
\stackrel{0}{ } \\
z\end{array}$ & 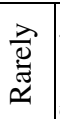 & 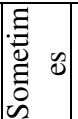 & $\underbrace{\stackrel{\Xi}{0}}_{0}$ & $\begin{array}{l}\text { 岕 } \\
\stackrel{3}{<}\end{array}$ \\
\hline 1 & I write about my teaching experiences in a diary or a notebook. & & & & & \\
\hline 2 & I have a file where I keep my accounts of my teaching for reviewing purposes. & & & & & \\
\hline 3 & $\begin{array}{l}\text { I talk about my classroom experiences with my colleagues and seek their advice } \\
\text { /feedback. }\end{array}$ & & & & & \\
\hline 4 & $\begin{array}{l}\text { After each lesson, I write about the accomplishments/failures of that lesson or I talk } \\
\text { aboutthe lesson to a colleague. }\end{array}$ & & & & & \\
\hline 5 & I discuss practical/theoretical issues with my colleagues. & & & & & \\
\hline 6 & I observe other teachers' classrooms to learn about their efficient practices. & & & & & \\
\hline 7 & I ask my peers to observe my teaching and comment on my teaching performance. & & & & & \\
\hline 8 & I think of using/introducing new teaching techniques in my classes. & & & & & \\
\hline 9 & I read books/articles related to effective teaching to improve my classroom performance & & & & & \\
\hline 10 & I participate in workshops/conferences related to teaching/learning issues. & & & & & \\
\hline 11 & I think of writing articles based on my classroom experiences. & & & & & \\
\hline 12 & $\begin{array}{l}\text { I look at journal articles or search the internet to see what the recent developments in my } \\
\text { profession are. }\end{array}$ & & & & & \\
\hline 13 & $\begin{array}{l}\text { I carry out small scale research activities in my classes to become better informed of } \\
\text { learning/ teaching processes. }\end{array}$ & & & & & \\
\hline 14 & $\begin{array}{l}\text { I think of classroom events as potential research topics and think of finding a method } \\
\text { or investigating them }\end{array}$ & & & & & \\
\hline 15 & I think about my students' emotional responses to my instructions. & & & & & \\
\hline 16 & $\begin{array}{l}\text { When a student is having an emotional problem or is neglected by his/her peers, I try to } \\
\text { spend more time with him/her. }\end{array}$ & & & & & \\
\hline 17 & Before and after teaching, I think about aspects of lesson my students liked/disliked. & & & & & \\
\hline 18 & $\begin{array}{l}\text { I ask my students to write/talk about their perceptions of my classes and the things they } \\
\text { liked/disliked about it. }\end{array}$ & & & & & \\
\hline 19 & I talk to my students to learn about their learning styles and preferences. & & & & & \\
\hline 20 & $\begin{array}{l}\text { I talk to my students to learn about their family backgrounds, hobbies, interests and } \\
\text { abilities. }\end{array}$ & & & & & \\
\hline
\end{tabular}




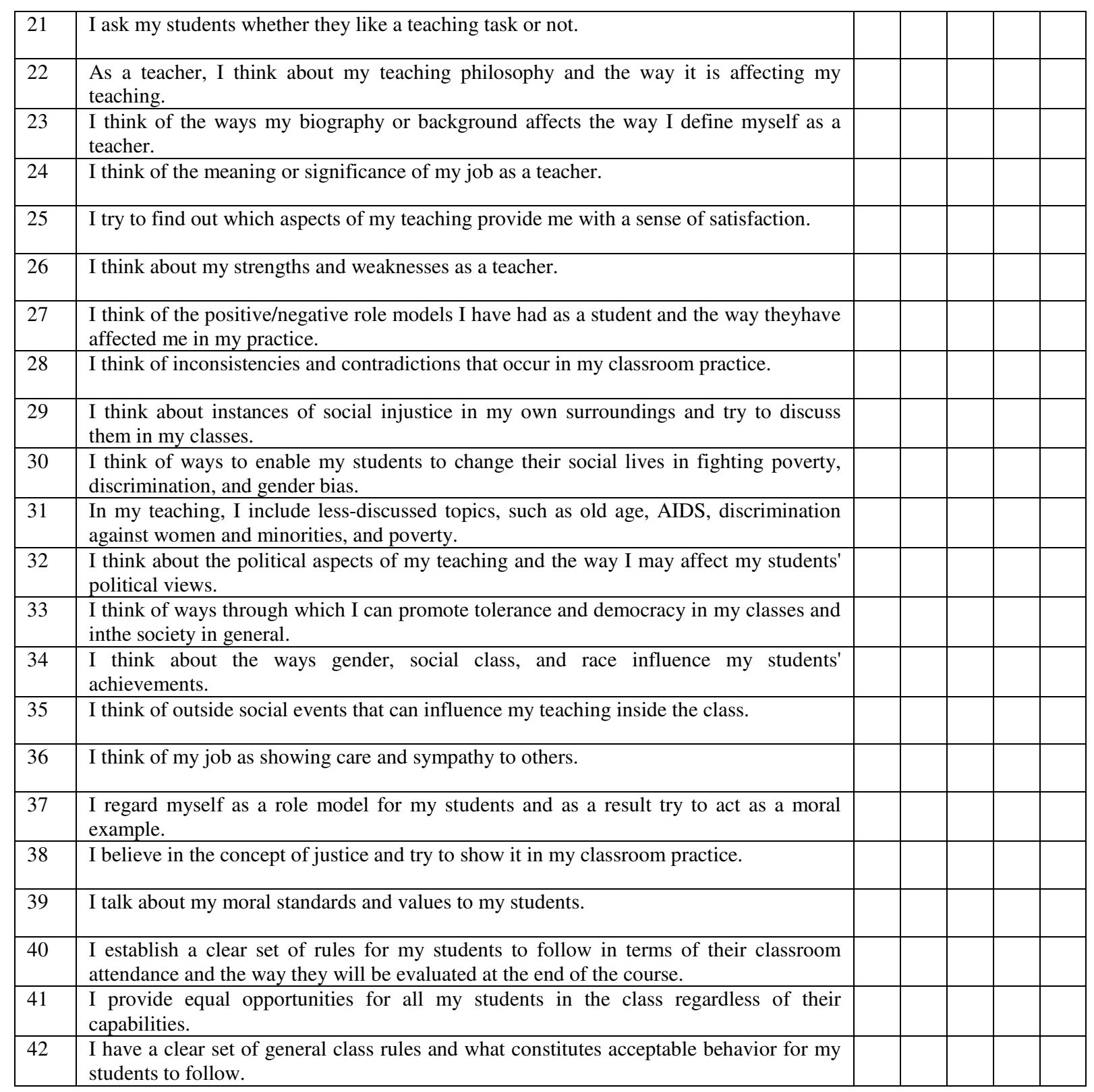

